\title{
What Drives the Environmental Performance? Evidence from Asian Countries
}

\author{
Haishi Li ${ }^{1,2}$, Xiangyi Xu ${ }^{1,2}$, Muhammad Zahid Rafique ${ }^{3 *}$, Syed Asif Ali Naqvi \\ Abdul Majeed Nadeem ${ }^{4 * *}$ \\ ${ }^{1}$ School of Management, Shandong University, Jinan, China \\ ${ }^{2}$ Corporate Governance Research Center, Shandong University, Jinan, China \\ ${ }^{3}$ Centre for Economic Research, Shandong University, Jinan, China \\ ${ }^{4}$ Department of Economics, Government College University, Faisalabad, Pakistan
}

Received: 27 August 2020

Accepted: 3 December 2020

\begin{abstract}
The environmental performance concern exists globally in spite of various efforts at state levels. This study is an effort to identify the key factors for environmental performance in 34-Asian countries using data period of 2006-2017. The most updated panel study techniques are employed. The existence of cross-sectional dependence (CD) is confirmed by CD tests. The results of the second-generation panel unit root test lead to apply the Westerlund panel cointegration test, which confirms the long- run co integration in the panel countries. Augmented Granger Causality test with error correction term is applied for long- run association. A bi-directional causality between EPI and GDP while uni-directional causality between EPI and forest area is founded. A feedback hypothesis between environmental performance and renewable energy while conservation hypothesis between EPI and food production index holds. The results of FMOLS show that renewable energy and forest area improve while food production index and fertilizer use reduce the environmental performance significantly in Asian countries. The introduction of eco-innovations in production technologies, eco-friendly methods in agriculture sector and forest area enhancement is suggested for improving environmental performance in the region.
\end{abstract}

Keywords: environmental performance, food production index, renewable energy, fertilizer, forest area, Asia

\section{Introduction}

For the past twenty years, public concerns on environmental issues both at the micro and macroeconomic level have been increasing due to rising

*e-mail: zahid716@sdu.edu.cn

**e-mail: majeednadeem@gcuf.edu.pk environmental problems and their harmful effects on environmental health and ecosystem vitality [1]. The rapid pace of growth in different sectors of the global economy has resulted in a wider range of negative environmental consequences and as a result of this, the focus of scientific communities, worldwide, has been directed to seek a balance between socio-economic, political and environmental conditions [2]. A series of efforts such as "Declaration of the UN conference on 
Human Environment" in 1972; the Rio Earth Summit in 1992, Kyoto Protocol, Millennium Declaration 2000, and Action Plan for 2016-2030 have been agreed upon and implemented globally for environmental protection by the United Nations (UN).

The pressure on governments to improve their environmental performance has been increasing globally [2]. Under the 2030 Agenda for Sustainable Development, the countries are now answerable to its citizens to provide information on their environmental policies for pollution control and natural resource management to ensure national sustainability. Different aspects of environmental performance have been the area of research interest in the business at microlevel, but very limited literature exists at macro-level $[1,3]$. At micro-level, the environmental performance analysis provides guidelines to make decisions for investment, while at macro-level; it shows the country's ability to produce environmental goods at large. The environmental outcome of a country depends on its industrial and services sectors, and the evaluating factors held responsible for environmental performance plays a crucial role in policy development as well as the measurement of policy outcomes for the country [4-8]. Environmental Performance Index (EPI) highlights a country's efforts against the environmental pressures being faced by it. Thus, analyzing the EPI's behavior and influencing factors will provide a strong base for effective policymaking. This can help in understanding the determinants of environmental progress and maximizing the rate of return on investment in environmental management to ensure environmental sustainability [2]. Environmental Sustainability Index (ESI) was first coined to quantify the sustainability metrics in 2000 by the Yale Center for Environmental Law and Policy (YCELP) and the Center for Earth Information Science Information Network (CIESIN) at Columbia University. ESI could not serve as a concrete document to guide the policymakers since it was based on broad-spectrum sustainability metrics, Natural Resource Endowments (NRE), pollution trends, Environmental Management's Efforts (EME), Global Common-Pool Resource Management (GCPRM) and society's ability to improve environment). Late on, the EPI concept, based on a narrow set of indicators, was introduced. The choice of EPI was based on the fact that it can conveniently measure and compare the environmental performance of a nation over time to hold accountable the concerned stakeholders (governments) to strengthen the effectiveness of policies. The EPI focuses on two basic aspects of sustainable development: firstly, the environmental health that develops as a result of economic growth and prosperity and secondly, the ecosystem vitality which depends on industrialization and urbanization [9].

The effects of environmental change are rising, and no part of the world is immune. Asia is the biggest continent globally with regard to land and population having the world's most carbon emission countries and polluted cities. Between 1990 to 2014, the per capita carbon emission has increased by $259 \%, 333 \%$ and $184 \%$ in India, China, and Indonesia respectively [10]. Asian region is facing rigorous issues of biodiversity loss, decrease in agriculture yield, accessibility of clean and safe drinking water, and deforestation putting drastic negative impacts on the environmental performance and welfare [2, 3, 11, 12]. Environmental conditions proxied by greenhouse effect, energy utilization and environmental performance proxied by EPI are main challenges in the Asian region. The 2018 EPI reports that the Asian countries are worst on the basis of environmental performance across the globe. This region is growing economically rapidly but environmental governance is very badly affecting the environmental performance [3]. Environmental degradation causes the death of about 1.6 million individuals in China annually [13] while the Southeast Asian region is also anticipated to endure $11 \%$ of Gross Domestic Product (GDP) loss by 2100 [14]. Environmental degradation has been articulated as habitat destruction, logging, less fertile soils, loss of freshwater availability, depletion and scarcity of natural resources, indefensible forest management and an acute rate of biodiversity loss [15]. Since, the economy and the environment act as two parts of a whole, both interlinked with each other via consumption and production sectors. Thus, the aim of economic policies should be to ensure environmental sustainability without hampering economic development.

The literature has widely debated the environmental outcome mostly considering carbon emission from a wider set of macro-economic variables [16-21]. But, a single variable cannot represent the complex and dynamic system of environmental performance [4-7, 16].

The current study serves as the pioneering effort to evaluate the influence of selected macroeconomic variables on multidimensional environmental performance indicator (EPI) since the existing literature in the domain of environmental economics has centered its attention to compare the year wise environmental performance using cross-sectional data [2]. This analysis will help in evaluating environmental performance over time and designing long-term planning for environmental sustainability. This will not only be helpful for the governments to gauge the outcome of their previous efforts but also to formulate the effective environmental policies and to put these policies into practice for improving the environmental performance in future. This study will fill the research gap in the following ways. Firstly, the research outcome will raise the public's interest and attention at large; political parties may put the study implications into their government's agenda for environmental sustainability. Since today's world witnesses a new age of policymaking based on data-driven environmental analysis, it will help identify problems and track time trends to identify best practices and optimize the 
fruits of environmental protection measures. Secondly, the research findings will provide ground for policy reformulation by understanding the environmental progress determinants in this region specifically, while ensuring sustainable development in the globe generally.

The remainder of this paper is presented in the following way: the second part discusses brief literature review and theoretical framework, the third part is material and methods section, the fourth part is results and discussion and the fifth part is conclussions followed by acknowledgement and references.

\section{Literature Review and Theoretical Framework}

Environmental performance in manufacturing process is greatly improved by eco-innovation. The performance is improved by efficient resource usage, water and air pollution reduction and improving recycling in production process [23]. Eco-innovation reduces environmental pressure by improving energy efficiency and material use and is key to success of strategies for environmental performance [8, 24-26].

A study in European Union is conducted to evaluate the environmental performance for the period 2001 to 2013 by dividing into two groups; 2001-07 as economic growth and 2007 to 13 as sever crisis respectively. The study claims that environmental performance is greatly affected by production process and energy usage. The environmental performance is dismal during economic crisis as compared to growth period. The study found that environmental performance improved in both periods due to adoption of environmental technologies. The study suggests an improvement in the design of environmental and energy use policy especially giving subsidies for renewable energy adoption. Through environmental efficiency, productivity and competitiveness will be helpful in achieving environmental performance [27].

Relating environmental performance with socioeconomic and cultural factors, it is found that economic growth and EPI show an inverted U-shape relationship for the Middle East and Africa while an N-shape for European countries. No relationship exists in case of Asia. Life expectancy and population density affects positively and negatively the environmental performance in respective manner while most of the cultural factors affect statistically insignificant the environmental performance in the Middle East, Africa and Europe in contrast to Asia and Oceania [28].

Socio-economic and Environmental Performance Indices are meaningful to evaluate social, economic and environmental conditions of a country. EPI provides a strong analytical tool to evaluate the environmental policy of any country. A high level of carbon emissions in a country lowers its ranking in environmental performance and has strong association with its ranking on sustainable development and social progress index.
GDP and EPI are strongly correlated and a policy aimed at environment friendly economic growth may be helpful in achieving economic as well as environmental performance [29]. Environmental performance describes the pollution level of a country and is continuously changes over time. A comprehensive indicator to gauge the environmental performance is highly shown by EPI. How the environmental policy affects environmental performance of a country is highly debatable among policy makers and environmentalist. In addition to environmental policy, structural and economic characteristics, the institutional factors greatly affects the environmental performance [30].

Improving environmental quality is prerequisite for sustainable development. While investigating the effects of potentially - effective variables on environmental performance, it is found that economic growth, energy consumption per GDP, industrial structure and population growth are ranked from higher to lower level respectively [24].

Measuring the impact of sociopolitical and economic factors to environmental performance in a panel study, it is shown that democracy and social policy have positive while transport, infrastructure and consumptions of goods have negative impacts on environmental performance. Asian region has $26 \%$ achievement in environmental performance [31].

Evaluating environmental performance has now become an area of high interest among researchers in the public sector. Environmental performance analysis provides country's assessment and holding the governments accountable for its deterioration, continuous improvement in policy options and collective efforts on environmental progress (Organization for Economic Co-operation and Development [OECD]) [32]. The Rio Earth Summit emphasized that efforts should be moved at all levels towards the achievement of environmental sustainability. Concerns for environmental performance are still there in spite of the fact that rigorous efforts have been made to control environmental degradation and natural resource management at national level globally. But very little effort has been done to identify the success of such programs [4-8, 22, 27, 33-37]. This research gap is filled by the current study.

Economic theory (Environmental Kuznets Curve - [EKC]) maintains that environmental performance improves with a country's improvement in economic growth (GDP). Studies have also confirmed that countries at same level of economic growth have different environmental performance, thus it provides strong base for further evaluation to know about its behavior. Ecological Modernization Theory (EMT) and Ecological Kuznets Curve Theory (EKCT) have explained how various economic factors affect the environment and provide a strong theoretical background for this study. Both of these theories establish a curve-linear association between economy and environment over a period of time rather a linear 
relationship. Heavy extraction of natural resources in early phases of industrial development and use of less efficient technologies affect ecological system adversely. The EMT also explains the changing relationship between economic growth and environment and claims to elaborate on new conditions for environmental sustainability. A better environmental performance of a country leads to the production of environmental public goods and reduces greenhouse gases emission to protect global ecological system [7, 33, 35, 37]. Per capita GDP energy consumption of a country reflects energy efficiency and greatly affects environmental performance. Hojnik and Ruzzier [4] found that deforestation has an economical cost and serves as strong environmental indicators. A higher level of environmental degradation greatly affects the human health while higher affforestation activities greatly improve environmental performance and human health [38]. A careful selection of variables in the light of the extant literature is ensured to evaluate their effects on environmental performance in the study region.

\section{Materials and Methods}

\section{Data Specification}

The empirical analysis is performed by using panel data of 34 countries from Asia (Armenia, Azerbaijan, Bangladesh, Cambodia, China, Cyprus, Georgia, India, Indonesia, Iran, Iraq, Israel, Japan, Jordan, Kazakhstan, Kyrgyz Republic, Lebanon, Malaysia, Mongolia, Myanmar, Nepal, South Korea, Pakistan, Philippines, Russian Federation, Saudi Arabia, Sri Lanka, Tajikistan, Thailand, Turkey, Vietnam, Yemen, Uzbekistan, United Arab Emirates) from 2006 to 2017. The selected variables are EPI as a dependent while GDP per capita, fertilizer consumption, renewable energy use, forest area, and food production index are taken as independent variables. The EPI score measured on scale of 0-100 quantify and numerically rank counties on the basis of their environmental performance. EPI is calculated using 32 performance indicators across 11 issue categories related to environmental health and ecosystem vitality having 40 and 60 percent contribution in cumulative EPI score (https://epi. yale.edu/about-epi). Economic growth is measured by GDP per capita (constant 2010 USD); Renewable energy consumption ( $\%$ of total energy consumption); Fertilizer use (kilograms per hectare); Forest area (\% of total land) and Food production index (2004$2006=100$ covers food crops that are considered edible and contain nutrients collectively. All data is collected from World Development Indicators (WDI) of World Bank. The trend diagrams (Figs 1-6) show the overtime performance of selected variables in Asian countries. There is no normal trend in EPI improvement in Asian countries while the average EPI score (57.63) shows a significant margin of improvement in the environment

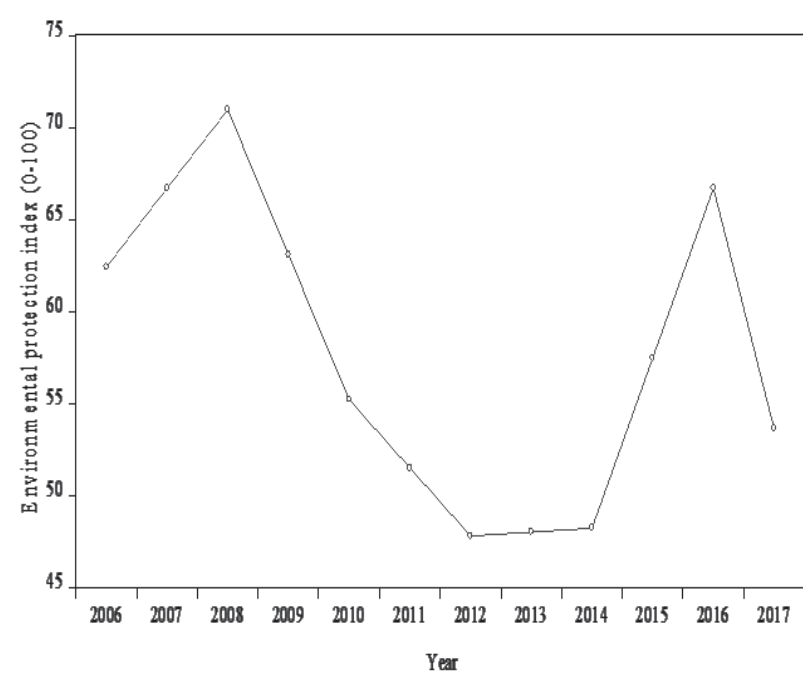

Fig. 1. The trends of environmental protection index in Asia (2006-2017).

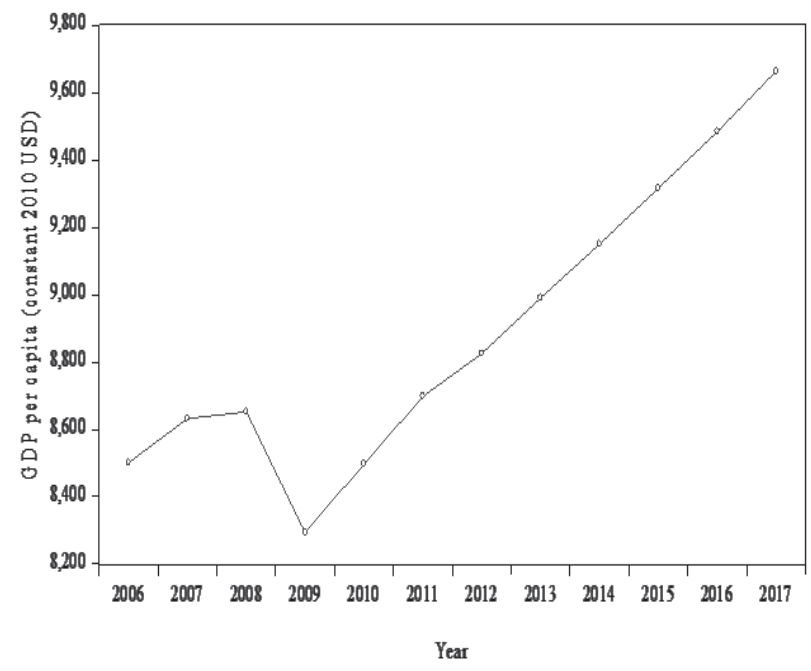

Fig. 2. The trends of GDP per capita in Asia (2006-2017).

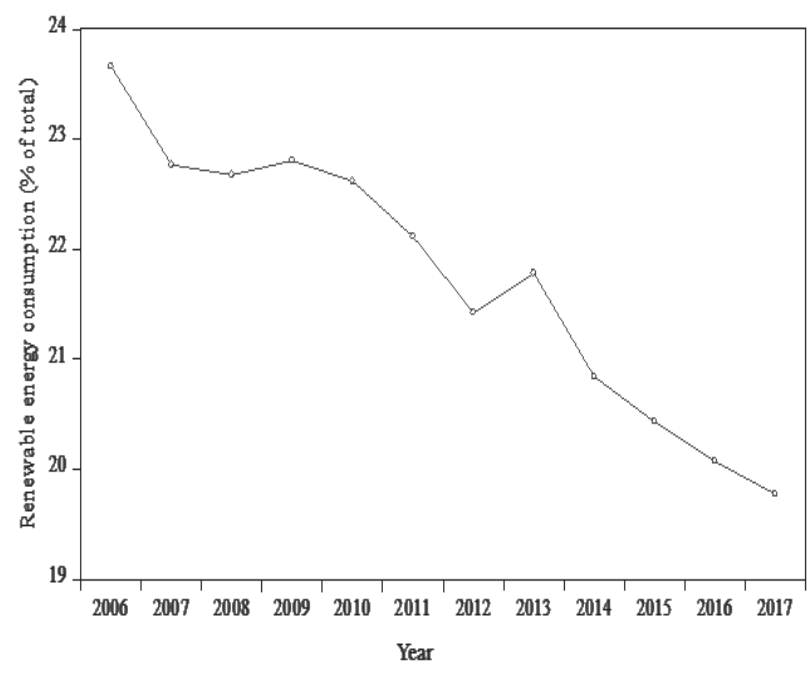

Fig. 3. The trends of renewable energy consumption in Asia (2006-2017). 


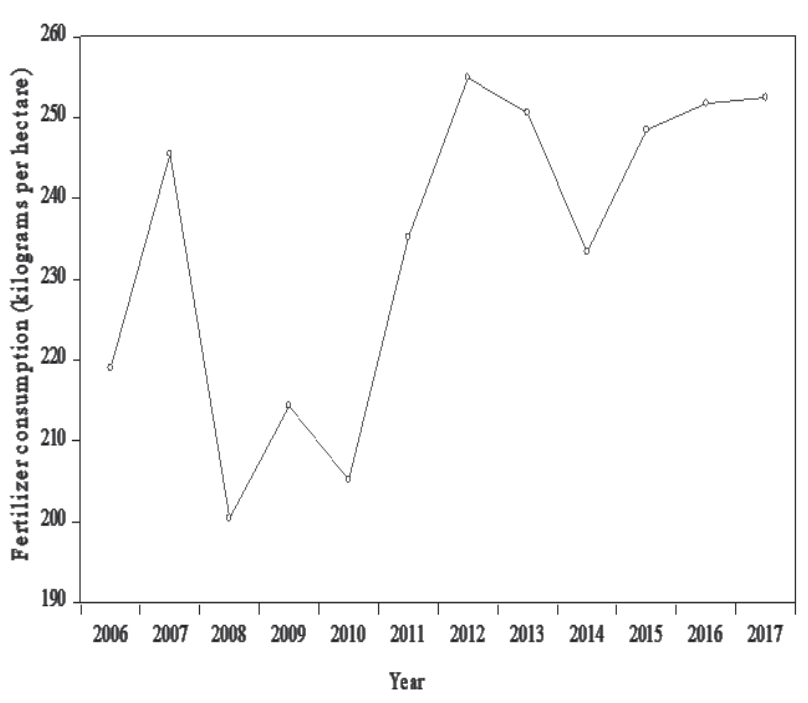

Fig. 4. Trends of fertilizer consumption in Asia (2006-2017).

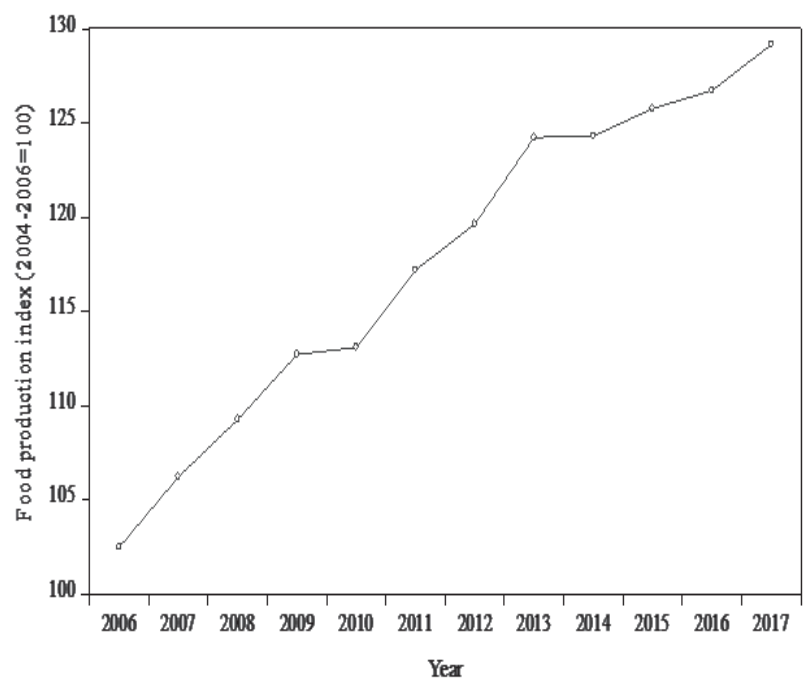

Fig. 5. Trends of food production index in Asia (2006-2017).

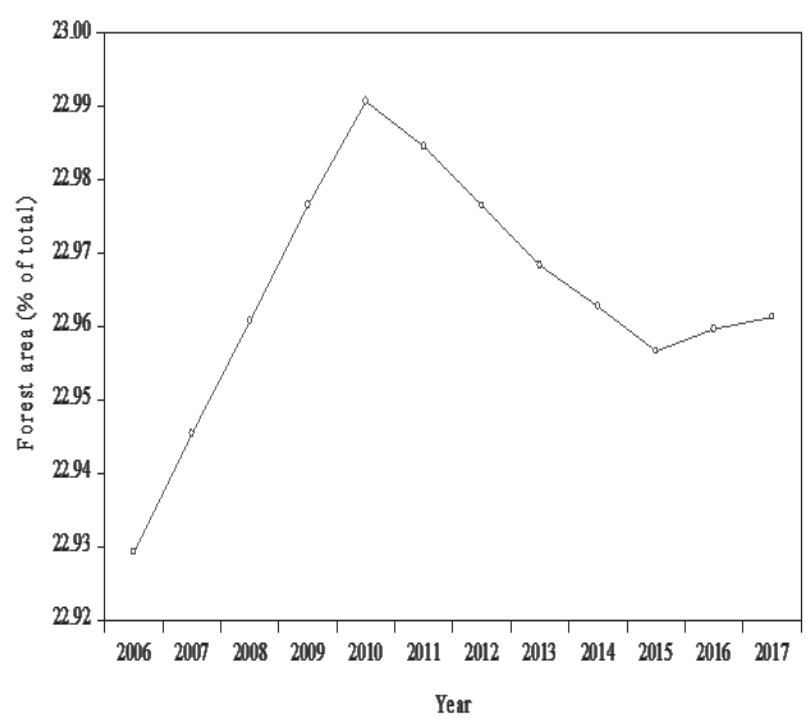

Fig. 6. Forest areas in Asia (2006-2017). performance. The rising economic growth, higher food consumption, and fertilizer use but the decreasing use of renewable energy (\%) in total energy consumption and forest areas in these countries may be considered as hindrance to environmental performance.

\section{Econometric Procedure}

The dynamic relationship between the selected variables is explored following the empirical model [39], and is expressed as:

$$
\mathrm{EPI}=f(\mathrm{GDP}, \mathrm{REN}, \mathrm{FOR}, \mathrm{FOD}, \mathrm{FER})
$$

It is transformed by taking natural logarithms on both sides, and the inclusion of the error term as follows:

$$
\begin{aligned}
\operatorname{lnEPI}_{\mathrm{it}}= & \beta_{\mathrm{i} 0}+\beta_{1 \mathrm{i}} \operatorname{lnGDP}_{\mathrm{it}}+\beta_{2 \mathrm{i}} \operatorname{lnREN}_{\mathrm{it}}+\beta_{3 \mathrm{i}} \operatorname{lnFOR_{it}} \\
& +\beta_{4 \mathrm{i}} \operatorname{lnFOD}_{\mathrm{it}}+\beta_{5 \mathrm{i}} \operatorname{lnFER}_{\mathrm{it}}+\varepsilon_{\mathrm{it}}
\end{aligned}
$$

The subscript $\mathrm{i}$ shows the cross-sections (total 34 countries), $t$ reveals the time series, the coefficients $\beta_{1}, \beta_{2}, \beta_{3}, \beta_{4}$, and $\beta_{5}$ are the slope coefficients, and $\varepsilon$ denotes the error term.

\section{Cross-Sectional Dependence (CD) Tests}

The CD may exist due to interaction among the selected variables as well as due to spatial effects and might give misleading results [40]. Thus, investigation of $C D$ is the initial step in the panel data analysis. The null hypothesis shows the absence of $\mathrm{CD}$ in the panel [41]. The CD test applied is expressed as [42]:

$$
\begin{gathered}
\mathrm{CD}=\sqrt{\frac{2 T}{N(N-1)}\left(\sum_{i=1}^{N-1} \sum_{j=i+1}^{N} \hat{\rho}_{i j}\right) \sim N(0,1) i, j} \\
\mathrm{CD}=1,2,3,4 \ldots \ldots \ldots 6 \ldots \ldots N \\
L M=\sqrt{\frac{2 T}{N(N-1)}\left(\sum_{i=1}^{N-1} \sum_{j=i+1}^{N} \hat{\rho}_{i j}\right) \frac{(T-k) \hat{\rho}^{2}{ }_{i j}-E(T-k) \hat{\rho}^{2}}{\operatorname{Var}(T-k) \hat{\rho}^{2}}{ }_{i j}}
\end{gathered}
$$

$\hat{\rho}_{i j}^{2}$ reveals the residual pair-wise correlation sample estimate, which is estimated with a simple linear regression equation. This study used parametric CD test $[43,44]$ as well as semi-parameter $\mathrm{CD}$ tests [45, 46]. These tests are useful for the panel, having a large number of cross-sections and small-time period.

\section{Panel Unit Root Tests}

The conventional unit root tests may provide biased results in the presence of CD. Pesaran [47] and Choi [48] proposed a unit root test in the presence of $\mathrm{CD}$, 
called Choi test [48]. Therefore, the CIPS [47] and CADF, the second-generation unit root test was used for the detection of the order of integration. This test has the ability to control the heterogeneity and $\mathrm{CD}$.

\section{Westerlund Panel Co Integration Test}

It is appropriate to apply the Westerlund cointegration test [49] in the presence of CD. This test establishes a model with panel specific-AR test statistic and the same-AR test statistic, which were estimated with the following equations [40]:

$$
\begin{gathered}
V R=\sum_{i=1}^{N} \sum_{t=1}^{T} \hat{E}_{i t}^{2} \hat{R}_{i}^{-1} \\
V R=\sum_{i=1}^{N} \sum_{t=1}^{T} \hat{E}_{i t}^{2}\left(\sum_{i=1}^{N} \hat{R}_{i}\right)^{-1}
\end{gathered}
$$

...where, $\hat{E}_{i t}^{2}=\sum_{j=1}^{t} \hat{e}_{i j}, \quad \hat{R}_{i}=\sum_{t=1}^{T} \hat{e}_{i t}^{2}$ and $\hat{e}_{i t}^{2}$ are residual from the panel regression model while VR shows the group mean variance-ratio statistic.

\section{Vector Error Correction Model (VECM) of Granger Causality}

The cointegration test only confirmed the causal association among the variables, but it cannot explore the direction of causality. The general method of Engle and Granger test is employed to determine the nexus between different variables. According to Peng and Liu, (2016), the use of Engel and Granger [50] causality test in first difference form by Vector Autoregressive (VAR) model fails to provide reliable results in the existence of cointegration. An additional variable such as error correction term (ECM) is helpful in order to find the long-run association. The augmented Granger causality test is used after the inclusion of ECM in a multivariate path order form. Following Engle and Granger [51], the VECM model is described below after modifying it according to the selected variables:

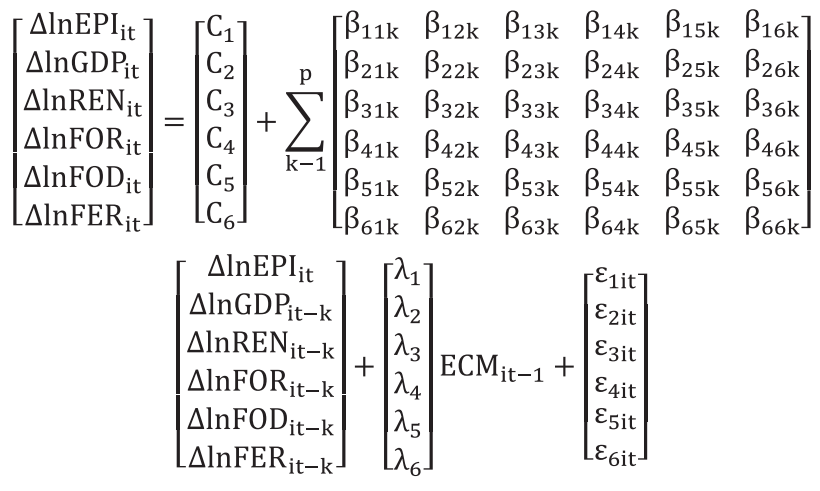

...where, $\mathrm{i}=1,2,3, \ldots \ldots \ldots \ldots, \mathrm{n} ; \mathrm{t}=\mathrm{p}+1, \mathrm{p}+2$,
T. $C_{i}, \beta_{i}$ and $\lambda_{i}$ shows the estimated parameters. $\Delta$ denotes the first difference, $\mathrm{ECM}_{\mathrm{it}-1}$ is the error term with one period lag and it was derived from the cointegration vector and $\varepsilon_{i t}$ are serially independent error terms with finite covariance matrix and zero mean The F-test is used to explore the causality [52]. The GDP Granger causes EPI in the short run when all the coefficients $\beta_{12 k} \forall \mathrm{k}$ is significantly different from zero in Eq. It is called a short-run causality test. The ECM coefficient shows the speed of deviations elimination from the long-run equilibrium. The significance of ECM is another test, which is called the long-run causality test.

\section{Fully Modified Ordinary Least Square (FMOLS)}

The FMOLS- a non-parametric analysis was used for the estimation of long-run elasticity coefficients. The FMOLS showed the ability to tackle endogeneity and serial correlation in the estimation of coefficients in panel data. The mathematical expression for the panel FMOLS estimator is expressed as [52, 53]:

$$
\widehat{\beta}_{\text {GFMOLS }}=\mathrm{N}^{-1} \sum_{\mathrm{i}=1}^{\mathrm{N}} \widehat{\beta}^{*}{ }_{\mathrm{FMOLS}, \mathrm{i}}
$$

...where $\hat{\beta}_{\text {FMOLS,i }}^{*}$ is the FMOLS estimator applied to the ith country, and the associated t-statistic is:

$$
\mathrm{t}_{\widehat{\beta}_{\mathrm{GFMOLS}}^{*}}=\mathrm{N}^{-1 / 2} \sum_{\mathrm{i}=1}^{\mathrm{N}} \mathrm{t}_{\widehat{\beta}_{\mathrm{FMOLS}, \mathrm{i}}^{*}}
$$

\section{Results and Discussion}

Table 1. shows the country-wise mean values for evaluating the country with respect to selected variables. Japan has the highest mean value for EPI with 75.32 followed by Malaysia (69.763) and Cyprus (69.02), while Bangladesh has the lowest value of (41.48) followed by Yemen (43.336). Nepal and Myanmar stood amongst highest renewable energy consuming countries with 87.03and $74.745 \%$ while Saudi Arabia, UAE and Iran are least consuming with $0.007,0.120$ and 0.954 respectively. Malaysia, Jordan and China amongst highest fertilizer use with $1674.00,804.863$, and $513.69 \mathrm{~kg} / \mathrm{Ha}$ respectively while Kazakhstan is lowest consuming only $3.065 \mathrm{Kg} /$ Ha. Forest area is highest in Japan (68.464) followed by Malaysia (66.888) while Saudi Arabia and Yemen are amongst lowest with 0.454 and 1.04 percent respectively. Food production index is highest in Cambodia and Bangladesh having 158.18 and 130.382 while Georgia and UAE are lowest with 76.819 and 90.150 respectively.

Table 2. Illustrates the descriptive statistics in the panel. A wide dispersion exists in most of the study variables: in economic growth, as evaluated by domestic product per capita (from 353.72 to 53926.60), and in 
Table 1. Means of selected variables in selected Asian countries (2006-2017).

\begin{tabular}{|c|c|c|c|c|c|c|}
\hline Countries & $\begin{array}{c}\text { Environmental } \\
\text { Performance index } \\
(0-100)\end{array}$ & $\begin{array}{l}\text { GDP per capita } \\
\text { (constant } 2010 \\
\text { USD) }\end{array}$ & $\begin{array}{c}\text { Renewable energy } \\
\text { consumption } \\
\text { (\% of total) }\end{array}$ & $\begin{array}{l}\text { Fertilizer use } \\
\text { (kilograms per } \\
\text { hectare) }\end{array}$ & $\begin{array}{l}\text { Forest area } \\
\text { (\% of total) }\end{array}$ & $\begin{array}{c}\text { Food production } \\
\text { index } \\
(2004-2006=100)\end{array}$ \\
\hline Armenia & 64.573 & 3573.969 & 9.797 & 36.963 & 11.647 & 128.386 \\
\hline Azerbaijan & 60.943 & 5591.231 & 2.928 & 19.288 & 12.675 & 130.762 \\
\hline Bangladesh & 41.482 & 834.283 & 40.055 & 246.653 & 11.048 & 130.382 \\
\hline Cambodia & 47.258 & 877.936 & 68.054 & 17.577 & 56.101 & 158.181 \\
\hline China & 52.614 & 5160.204 & 13.115 & 513.691 & 21.617 & 124.362 \\
\hline Cyprus & 69.027 & 29754.700 & 7.689 & 157.871 & 18.699 & 83.780 \\
\hline Georgia & 62.081 & 3347.973 & 32.988 & 101.781 & 40.511 & 76.819 \\
\hline India & 44.551 & 1465.557 & 39.443 & 163.928 & 23.505 & 129.541 \\
\hline Indonesia & 54.304 & 3349.757 & 38.199 & 203.947 & 51.561 & 129.214 \\
\hline Iran & 60.338 & 6311.515 & 0.954 & 96.701 & 6.564 & 106.886 \\
\hline Iraq & 44.051 & 4881.309 & 1.265 & 43.521 & 1.897 & 95.905 \\
\hline Israel & 68.968 & 31419.210 & 5.666 & 260.168 & 7.350 & 106.558 \\
\hline Japan & 75.320 & 45750.940 & 4.988 & 257.501 & 68.464 & 97.048 \\
\hline Jordan & 60.887 & 3507.370 & 2.947 & 804.863 & 1.100 & 126.658 \\
\hline Kazakhstan & 56.030 & 9615.195 & 1.458 & 3.065 & 1.227 & 123.901 \\
\hline Korea, Rep. & 66.316 & 22825.870 & 1.833 & 391.730 & 63.838 & 102.753 \\
\hline Kyrgyz Republic & 57.319 & 932.249 & 24.414 & 24.408 & 3.583 & 107.203 \\
\hline Lebanon & 60.924 & 7688.288 & 4.981 & 388.709 & 13.394 & 92.812 \\
\hline Malaysia & 69.763 & 9686.225 & 4.650 & 1674.631 & 66.888 & 121.479 \\
\hline Mongolia & 52.431 & 3195.911 & 3.778 & 25.766 & 8.092 & 133.552 \\
\hline Myanmar & 49.784 & 1081.070 & 74.745 & 16.313 & 47.122 & 128.553 \\
\hline Nepal & 55.633 & 617.530 & 87.103 & 40.135 & 25.364 & 123.143 \\
\hline Pakistan & 44.830 & 1085.190 & 46.300 & 131.589 & 2.105 & 120.554 \\
\hline Philippines & 63.528 & 2302.217 & 29.484 & 138.712 & 24.847 & 114.343 \\
\hline $\begin{array}{l}\text { Russian } \\
\text { Federation }\end{array}$ & 66.107 & 11048.900 & 3.415 & 15.659 & 49.711 & 126.551 \\
\hline Saudi Arabia & 62.694 & 20321.600 & 0.007 & 124.050 & 0.454 & 103.340 \\
\hline Sri Lanka & 63.453 & 3092.823 & 58.527 & 267.402 & 33.336 & 122.147 \\
\hline Tajikistan & 51.430 & 806.781 & 53.345 & 73.616 & 2.945 & 132.397 \\
\hline Thailand & 63.568 & 5278.827 & 22.702 & 152.199 & 31.894 & 117.722 \\
\hline Turkey & 61.308 & 12083.290 & 13.157 & 99.194 & 14.750 & 119.943 \\
\hline $\begin{array}{l}\text { United Arab } \\
\text { Emirates }\end{array}$ & 60.747 & 40875.520 & 0.120 & 870.845 & 3.814 & 90.150 \\
\hline Uzbekistan & 48.781 & 1528.909 & 2.518 & 202.204 & 7.648 & 135.955 \\
\hline Vietnam & 54.965 & 1420.693 & 37.420 & 386.261 & 45.997 & 124.687 \\
\hline Yemen & 43.336 & 1012.833 & 1.355 & 14.948 & 1.040 & 131.497 \\
\hline
\end{tabular}

renewable energy use (from 0.01 to 91.31); fertilizer use from 2026.90 to $1.08 \mathrm{Kg} / \mathrm{Ha}$; forest area from 68.48 to $0.45 \%$ of total land while food production index ranges from 195.03 to 63.03). On average, EPI is (57.63), with a minimum value of (25.32) and a maximum value of (84.50). 
Table 2. Descriptive Statistics of selected variables.

\begin{tabular}{|c|c|c|c|c|c|c|}
\hline Variables & Unit & Mean & Minimum & Maximum & $\begin{array}{c}\text { Standard } \\
\text { deviation }\end{array}$ & Data Source \\
\hline GDP per capita (GDP) & Constant 2010 USD & 8891.94 & 353.72 & 53926.60 & 11750.94 & WDI (2019) \\
\hline Renewable energy use (REN) & \% of total & 21.75 & 0.01 & 91.31 & 24.41 & WDI (2019) \\
\hline Fertilizer consumption (FER) & $\begin{array}{c}\text { Kilograms per } \\
\text { hectare }\end{array}$ & 234.29 & 1.08 & 2026.90 & 337.61 & WDI (2019) \\
\hline Forest area (FOR) & \% of total area & 22.96 & 0.45 & 68.48 & 21.33 & WDI (2019) \\
\hline Food production index (FOD) & $2004-2006=100$ & 117.56 & 63.03 & 195.03 & 21.37 & WDI (2019) \\
\hline Environmental Performance index (EPI) & $0-100$ & 57.63 & 25.32 & 84.50 & 12.77 & WDI (2019) \\
\hline
\end{tabular}

Table 3. and Table 4. illustrate the results of two CD tests applied showing that the null hypothesis of no CD is rejected. This implies that there are dependencies across countries such that a shock arises the rest of the sample countries.

The present study checks the stationarity of the study variables by employing second generation panel unit root tests due to the presence of CD. Results reported in Table 5 reveal that the null hypothesis cannot be rejected at level but after considering first difference levels of significance.

Table 6 reports the results of the Westerlund panel cointegration test. The calculated values for the panel suggest rejection of the null hypothesis of no cointegration. The results of this study endorse that there is cointegration between the underlying

Table 3. Residual CD tests results.

\begin{tabular}{|c|c|c|c|}
\hline CD tests & Test-stat. & Prob. & $\begin{array}{c}\text { Cross-sectional } \\
\text { dependence }\end{array}$ \\
\hline Pesaran CD & $47.051^{\mathrm{A}}$ & 0.000 & Exist \\
\hline Friedman & $219.534^{\mathrm{A}}$ & 0.000 & Exist \\
\hline Frees & $11.272^{\mathrm{A}}$ & 0.000 & Exist \\
\hline
\end{tabular}

${ }^{\mathrm{A}}$ significant at $1 \%$

Table 4. Results from the Pesaran (2004) cross-sectional independence test.

\begin{tabular}{|c|c|c|}
\hline Variable & CD-test & p-value \\
\hline $\operatorname{lnEPI}$ & $55.58^{* * *}$ & 0.000 \\
\hline $\operatorname{lnGDP}$ & $40.55^{* * *}$ & 0.000 \\
\hline $\operatorname{lnREN}$ & $4.53^{* * *}$ & 0.000 \\
\hline $\operatorname{lnFOR}$ & $20.26^{* * *}$ & 0.000 \\
\hline $\operatorname{lnFOD}$ & $28.27 * * *$ & 0.000 \\
\hline $\operatorname{lnFER}$ & $18.08^{* * *}$ & 0.000 \\
\hline
\end{tabular}

Notes: $* * *$ represents statistical significance at $1 \%$.

The Pesaran CD test is based on the null hypothesis of cross-sectional independence. variables and that they move together in the long run.

Table 7 reports the Granger causality test. The causality is observed between two variables when the present value of $y$ is predicted by the assistance of previous $\mathrm{x}$ values [52]. Results confirm the nexus between GDP and EPI, which was bi-directional in the panel. It implies that both of these variables cause each other. The rise in EPI because of the rise in renewable energy use was also observed in the panel. The $1 \%$ increase in the use of renewable energy generated $0.279 \%$ increase in the EPI.

Moreover, the feedback hypothesis of Granger causality was also established between EPI and renewable energy. It implies the environmental benefits of renewable energy. In the present study, the

Table 5. Results from the panel unit root test.

\begin{tabular}{|c|c|c|c|c|}
\hline \multirow{2}{*}{ Variable } & \multicolumn{2}{|c|}{ CIPS } & \multicolumn{2}{c|}{ CADF } \\
\cline { 2 - 5 } & Level & $\Delta$ & Level & $\Delta$ \\
\hline $\operatorname{lnEPI}$ & -1.246 & $-1.731^{\mathrm{A}}$ & -0.515 & $-3.087^{\mathrm{A}}$ \\
\hline $\operatorname{lnGDP}$ & -2.281 & $-1.875^{\mathrm{A}}$ & -1.593 & $-2.701^{\mathrm{A}}$ \\
\hline $\ln \mathrm{REN}$ & -2.271 & $-2.509^{\mathrm{A}}$ & -0.778 & $-2.504^{\mathrm{A}}$ \\
\hline $\operatorname{lnFOR}$ & -1.014 & $-0.833^{\mathrm{B}}$ & -0.919 & $2.610^{\mathrm{C}}$ \\
\hline $\operatorname{lnFOD}$ & -2.629 & $-3.403^{\mathrm{A}}$ & -0.760 & $-2.567^{\mathrm{A}}$ \\
\hline $\ln \mathrm{FER}$ & -3.233 & $-3.359^{\mathrm{A}}$ & -0.760 & $-3.852^{\mathrm{A}}$ \\
\hline
\end{tabular}

Note: A significant at 1\%, B significant at 5\%, C significant at $10 \%$. Critical values of the CIPS are not provided because of concision but may be given when requested. Both the CIPS and CADF are determined from the null hypothesis of cross-sectional independence.

Table 6. Westerlund panel cointegration test.

\begin{tabular}{|c|c|c|c|}
\hline Null hypothesis & \multicolumn{2}{|c|}{ Variance ratio } & Conclusion \\
\hline \multirow{2}{*}{ No cointegration } & Statistics & Prob. & $\begin{array}{c}\text { Co-integration } \\
\text { exist }\end{array}$ \\
\cline { 2 - 3 } & $2.229^{\mathrm{B}}$ & 0.013 & \\
\hline
\end{tabular}

Note: ${ }^{\mathrm{B}}$ significant at $5 \%$ 
Table 7. Panel Granger F-test results.

\begin{tabular}{|c|c|c|c|c|c|c|c|c|}
\hline Panel & Variables & $\operatorname{lnEPI}$ & $\operatorname{lnGDP}$ & $\ln R E N$ & $\operatorname{lnFOR}$ & $\operatorname{lnFOD}$ & lnFER & ECM \\
\hline \multirow{9}{*}{$\begin{array}{c}\text { Asian } \\
\text { countries }\end{array}$} & $\operatorname{lnEPI}$ & & $81.675^{\mathrm{A}}$ & $5.677^{\mathrm{C}}$ & 1.829 & 0.183 & 3.481 & $-0.273^{\mathrm{A}}(0.000)$ \\
\hline & $\operatorname{lnGDP}$ & $35.365^{\mathrm{A}}$ & & 3.888 & $4.655^{\mathrm{C}}$ & 0.422 & 0.856 & $0.001(0.746)$ \\
\hline & $\operatorname{lnREN}$ & $5.372^{\mathrm{C}}$ & $4.607^{\mathrm{C}}$ & & $9.216^{\mathrm{A}}$ & 3.091 & 1.351 & $0.001(0.563)$ \\
\hline & $\operatorname{lnFOR}$ & $1443.153^{\mathrm{A}}$ & 0.144 & 0.288 & & 0.304 & 0.785 & $-0.001(0.782)$ \\
\hline & $\operatorname{lnFOD}$ & $14.679^{\mathrm{A}}$ & 1.616 & $8.471^{\mathrm{A}}$ & 1.925 & & 0.081 & $-0.001^{\mathrm{A}}(0.002)$ \\
\hline & $\operatorname{lnFER}$ & $36.674^{\mathrm{A}}$ & $11.504^{\mathrm{A}}$ & 2.254 & 2.137 & 0.122 & & $-0.014^{\mathrm{A}}(0.000)$ \\
\hline & \multicolumn{8}{|c|}{ Causality Hypothesis (Dependent Variable: EPI) } \\
\hline & \multicolumn{2}{|c|}{ Growth } & \multicolumn{2}{|c|}{ Conservation Hypothesis } & \multicolumn{2}{|c|}{ Feedback Hypothesis } & \multicolumn{2}{|c|}{ Neutrality } \\
\hline & & & \multicolumn{2}{|c|}{ EPI FOR; EPI FOD; EPI FER } & \multicolumn{2}{|c|}{ EPI GDP; EPI REN } & & \\
\hline
\end{tabular}

${ }^{\mathrm{A}}$ significant at $1 \%,{ }^{\mathrm{B}}$ significant at $5 \%,{ }^{\mathrm{C}}$ significant at $10 \%$; Lag length: 2

$1 \%$ increase in forest area associates with the $4.502 \%$ increase in the EPI. The uni-directional causality was also established from EPI to the forest area. The current study also endeavored to discover the association between food production index and EPI. The results confirmed $0.415 \%$ reduction in EPI due to a $1 \%$ increase in the food production index. The conservation hypothesis was also holding between EPI and food production index, which implies that EPI causes food production in the panel.

Table 8 reports the FMOLS model regression analysis results. The results showed the $0.265 \%$ reduction in the EPI score due to a $1 \%$ increase in fertilizer consumption, which implies that the fertilizer use was not beneficial for the environment. The conservation hypothesis was also holding between EPI and fertilizer use, which implies that EPI causes fertilizer consumption in the panel. The Granger causality analysis also revealed uni-directional causality from forest area to GDP, GDP to renewable energy, forest area to renewable energy, renewable energy to food production index, and GDP to fertilizer consumption.

In particular reference to Asia, it has been frequently observed that growth in GDP has been achieved at the cost of environmental deterioration. With the persistent growth in economies in the forthcoming decades, the critical policymaking theme by Asian states will be to find a balanced approach towards development and sustainability by introducing practical policies and establishing institutions [54]. Keeping in view the empirical findings of the statistically positive association of GDP with an environmental performance by Xavier et al., [5] and Gallego-Álvarez et al., [1], the current study could not discover any statistically significant association between the said variables. This variance in the study findings may be explained through multiple reasons. First, the sample size of the current study may be one of the reasons. We employed a large sample of 34 countries possessing diverse physical and demographic characteristics and resultantly caused variance in the study results. Second, the use of different indices for the measurement of environmental performance may explain the variance also. The current study used EPI in contrast to other studies which employed ESI. The two indices are different in a number of ways. For instance, the EPI evaluates present environmental situations, while ESI assesses long-term environmental path highlighting the sustainability of the environment. The EPI addresses the government-controlled domain,

Table 8. Results of FMOLS Regression (Dependent variable: EPI).

\begin{tabular}{|c|c|c|c|c|}
\hline \multirow{2}{*}{ Variables } & \multicolumn{3}{|c|}{ Results of FMOLS Regression (Dependent variable: $\operatorname{lnEPI})$} \\
\cline { 2 - 5 } & Coefficient & Standard Error & t-statistics & Prob. \\
\hline $\operatorname{lnGDP}$ & 0.039 & 0.120 & 0.322 & 0.748 \\
\hline $\operatorname{lnREN}$ & $0.279^{\mathrm{C}}$ & 0.155 & 1.805 & 0.072 \\
\hline $\operatorname{lnFOR}$ & $4.502^{\mathrm{A}}$ & 1.208 & 3.725 & 0.000 \\
\hline $\operatorname{lnFOD}$ & $-0.415^{\mathrm{B}}$ & 0.174 & -2.394 & 0.017 \\
\hline $\operatorname{lnFER}$ & $-0.265^{\mathrm{A}}$ & 0.078 & -3.403 & 0.001 \\
\hline
\end{tabular}

Note: ${ }^{\mathrm{A}}$ significant at $1 \%,{ }^{\mathrm{B}}$ significant at $5 \%,{ }^{\mathrm{C}}$ significant at $10 \%$ 
while the ESI takes into consideration a broad array of determinants that may influence sustainability employing pressure-state-response model. EPI incorporates several levels with dual objectives, six categories and 25 indicators, while the ESI includes five factors, 21 indicators and 76 variables.

Regarding renewable energy use, our findings align with the studies conducted in other perspectives. Production eco-efficacy uses energy intensity as an approximate indicator. Lower energy intensity, a vital aspect of environmental performance with reference to resource conservation, is empirically discovered to possess association with lower $\mathrm{CO}_{2}$ emissions. Hence, progress in the domain of production eco-efficiency is likely to produce several encouraging effects which include energy savings and reduction in emissions [55, 56]. Charfeddine and Kahia [57] suggested a number of policy options to promote renewable energy, i.e. (a) establishment of renewable energy as a compulsory target, (b) creation of renewable energy regulatory body, (c) decrease in subsidies on technologies using conventional energy, (d) insertion of externality cost of energy production in the prices. We also suggest enhancing renewable energy consumption (solar, wind, geothermal, hydropower, and biomass) for the protection of the environment.

Forest increase can help to combat carbon emission via photosynthesis and then remain stored as biomass subsequently used as input in the environment via decomposition process [58]. Moreover by controlling deforestation can reduce carbon emissions up to 7-billion metric tons annually, $42 \%$ of the total carbon emission can be reduced by reforestation of global grazing land alone [59]. Developing new forest area (Affforestation), adding trees to existing forest land (Reforestation) and other forest restoration activities are an effective tools to remove carbon dioxide concentration from the atmosphere [60]. A careful operational practice for forest management may improve economic and environmental performance for sustainability. Efficient harvesting techniques not only affect cost, productivity but environment as well [61]. Sustainable forest management through "Forest Management Certification" a newly introduced management practices strongly improve environmental performance [62]. So, our findings on positive and significant impact of forest area for environmental performance are in lined with literature.

Environmental impacts of food production occur from production to consumption level. Impacts at production side often depend on activities at consumption side, and improvement options for food industry might often involve changes that result in large savings at other nodes rather than for the industry's own emissions [63]. With ever increasing population, minimizing environmental impacts associated with food production is accepted as key aspect to sustainability. Sustainability and optimum food production can be achieved by adopting cleaner production (CP) and reducing operational efficiency. Life cycle assessment (LCA) and CP are ensuring environmental protection globally [64]. Our results are also in lined with this literature.

Declining soil fertility is a major issue in developing countries due to intensive cultivation and deforestation. To sustain the ever-increasing world population, fertilizer use is best option, but environmental concerns are threatening. It is estimated that $70 \%$ of plant nutrients will have to supplement through fertilizer use by 2020. Strong technical and socio-economic measures are desired for sustained production and to reduce the incidence of global warming, ozone depletion, shortage of freshwater bodies and acid rains [65]. Negative environmental effects of fertilizer use in the form of Ammonia $\left(\mathrm{NH}_{3}\right)$ and Nitrous Oxide $\left(\mathrm{N}_{2} \mathrm{O}\right)$ emission are confirmed. Therefore, reducing the fertilizer application may affect positively overall environmental improvement. One way of achieving is efficiency is to shift from crops of higher pollutant emissions to lower ones [66]. The efficient production and use of fertilizers for improving nutrient efficiency and minimizing environmental effects via non-conventional fertilizer application are viable solutions [67].

\section{Conclusions}

The findings of our study have developed a greater understanding on EPI and can be effective for ensuring environmental sustainability. The main objective of the current study is to evaluate the outcome of past environmental protection policies and to suggest improvement future policies. The procedure for completing the research comprised different steps. In the first step, we select important macro-economic variables like GDP, food production index, use of renewable energy, forest area and fertilizer use to gauge their impacts on environmental performance index in 34- Asian countries. To check the CD among countries, we applied $\mathrm{CD}$ test. Based on $\mathrm{CD}$ results, second generation panel unit root tests are carried out due to $\mathrm{CD}$ existence. Then Westerlund cointegration tests are applied to check the existence of cointegration, and FMOLS methodology is selected for regression analysis. Vector Error Correction model of granger causality is also applied to check the direction of causality among variables.

The regression result reveals that GDP exerts a positive but insignificant association with EPI. The use of renewable energy was significantly responsible for the improvement in EPI. The increase in forest area is significantly associated with EPI, and the food production index and fertilizer use negatively and significantly affect the EPI. The conservation hypothesis was holding between EPI and food production index; EPI and fertilizer use; EPI and forest area. Results of Panel Granger F-test confirmed the bi-directional causality between GDP and EPI and uni-directional 
causality from EPI to forest area; from forest area to GDP; GDP to renewable energy; forest area to renewable energy; renewable energy to food production index, and GDP to fertilizer consumption.

In the face of the insufficient governmental capability for the enforcement of regulations in most of the Asian developing economies, the introduction of the market-based approach is likely to initiate an automated system because the industrial sector will start reaping the advantages of efforts aimed at the protection of the environment. Moreover, most of the Asian states are undergoing the development phase, where the quality of the environment is generally compromised.

Therefore, the introduction of eco-innovation in production technologies may act as a means to surpassing growth-oriented environmental degradation and accomplishing higher output and ecoefficiency simultaneously. For realizing technological advancement, policymakers should encourage research activities at academic and corporate levels, and support their use in both publicly and privately-owned organizations [23]. This kind of hybrid partnership in Asian states can serve as a novel way in the direction of sustainable growth that channels collective social actions. The results suggest that the environment is adversely affected because of the use of fertilizers for meeting superfluous food demand. In the light of econometric evidence, this study recommends using eco-friendly methods in the agriculture sector, for instance, using clean water, curtailing greenhouse emissions, and applying minimal amounts of chemical fertilizers. These steps can bring increased agricultural output and help in fighting against global warming through a reduction in carbon emissions. Last but not least, forest planting is an effective way to make better country environmental performance.

The future research should focus on evaluating the situation and influencing factors on socio-economic indices such as Global Competitive index; Ease of doing business; Corruption perceptions and Social Progress index which might be the limitations of the current study. This will give an insight into the area of performance of specific policies and could be used for future improvements in the study region as well as globally.

\section{Acknowledgements}

This research was funded by National Natural Science Foundation of China (No. 71872101); Social Science Foundation of Shandong Province (No. 17BGLJ08).

\section{Conflict of Interest}

The authors declare no conflict of interest.

\section{References}

1. GALLEGO-ÁLVAREZ I., VICENTE-GALINDO M.P., GALINDO-VILLARDÓN M.P., RODRÍGUEZROSA M. Environmental performance in countries worldwide: Determinant factors and multivariate analysis. Sustainability (Switzerland). 2014.

2. PIMONENKO T., LYULYOV O., CHYGRYN O., PALIENKO M. Environmental Performance Index: relation between social and economic welfare of the countries. Environmental Economics, 9 (3), 1, 2018.

3. HALKOS G., ZISIADOU A. Relating environmental performance with socioeconomic and cultural factors. Environmental Economics and Policy Studies, 20 (1), 69, 2018.

4. HOJNIK J., RUZZIER M. What drives eco-innovation? A review of an emerging literature. Environmental Innovation and Societal Transitions, 19, 31, 2016.

5. XAVIER A.F., NAVEIRO R.M., AOUSSAT A., REYES T. Systematic literature review of eco-innovation models: Opportunities and recommendations for future research. Journal of Cleaner Production. Elsevier Ltd, 2017, April 15.

6. KELLENS K., BAUMERS M., GUTOWSKI T.G., FLANAGAN W., LIFSET R., DUFLOU J.R. Environmental Dimensions of Additive Manufacturing: Mapping Application Domains and Their Environmental Implications. Journal of Industrial Ecology, 21 (S1), S49, 2017.

7. TSENG M.L., CHANG C.H., LIN C.W., NGUYEN T.T.H., LIM M.K. Environmental responsibility drives board structure and financial and governance performance: A cause and effect model with qualitative information. Journal of Cleaner Production, 258, 120668, 2020.

8. CHAPPIN M.M.H., VERMEULEN W.J.V., MEEUS M.T.H., HEKKERT M.P. Enhancing our understanding of the role of environmental policy in environmental innovation: adoption explained by the accumulation of policy instruments and agent-based factors. Environmental Science and Policy, 12 (7), 934, 2009.

9. HSU A., LLOYD A., EMERSON J.W. What progress have we made since Rio? Results from the 2012 Environmental Performance Index (EPI) and Pilot Trend EPI. Environmental Science and Policy, 33, 171, 2013.

10. OLIVER J., JANSSENS-MAENHOUT G., MUNTEAN M., PETERS J. Trends in Global $\mathrm{CO}_{2}$ emissions: 2015 report, 2015.

11. ALMEIDA T.A.N., GARCÍA-SÁNCHEZ I.M. Sociopolitical and economic elements to explain the environmental performance of countries. Environmental Science and Pollution Research, 24 (3), 3006, 2017.

12. FAKHER H., ABEDI Z. Relationship between Environmental Quality and Economic Growth in Developing Countries (based on Environmental Performance Index). Environmental Energy and Economic Research, 1 (3), 299, 2017.

13. RAITZER D.A., BOSELLO F., TAVONI M., ORECCHIA C., MARANGONI G., NUELLA SAMSON J.G. Southeast Asia and The Economics of Global Climate Stabilization. ADB, 2015.

14. AHMED M., SUPHACHALASAI S. Assessing the Costs of Climate Change and Adaptation in South Asia. Asian Development Bank. Retrieved from http://www.adb. org/sites/default/files/pub/2014/assessing-costs-climatechange-and-adaptation-south-asia.pdf, 2014. 
15. AKAO K.I. Preference constraint for sustainable development. Environmental Economics and Policy Studies, 16 (4), 343, 2014.

16. DOĞAN B., DRIHA O.M., BALSALOBRE LORENTE D., SHAHZAD U. The mitigating effects of economic complexity and renewable energy on carbon emissions in developed countries. Sustainable Development, sd. 2125, 2020.

17. SHAHZAD U., FERRAZ D., DOĞAN B., APARECIDA DO NASCIMENTO REBELATTO D. Export product diversification and $\mathrm{CO}_{2}$ emissions: Contextual evidences from developing and developed economies. Journal of Cleaner Production, 276, 124146, 2020.

18. FATIMA T., SHAHZAD U., CUI L. Renewable and nonrenewable energy consumption, trade and $\mathrm{CO}_{2}$ emissions in high emitter countries: does the income level matter? Journal of Environmental Planning and Management, 1, 2020.

19. SHAHZAD U., FAREED Z., SHAHZAD F., SHAHZAD $\mathrm{K}$. Investigating the nexus between economic complexity, energy consumption and ecological footprint for the United States: New insights from quantile methods. Journal of Cleaner Production, 279, 123806, 2021.

20. SHAHZAD U. Environmental taxes, energy consumption, and environmental quality: Theoretical survey with policy implications. Environmental Science and Pollution Research, 27 (20), 24848, 2020.

21. SARWAR S., SHAHZAD U., CHANG D., TANG B. Economic and non-economic sector reforms in carbon mitigation: Empirical evidence from Chinese provinces. Structural Change and Economic Dynamics, 49, 146, 2019.

22. ZENG J., YUAN M., FEIOCK R. What Drives People to Complain about Environmental Issues? An Analysis Based on Panel Data Crossing Provinces of China. Sustainability, 11 (4), 1147, 2019

23. YURDAKUL M., KAZAN H. Effects of Eco-Innovation on Economic and Environmental Performance: Evidence from Turkey's Manufacturing Companies. Sustainability, $12(8), 1,2020$.

24. FAKHER H., ABEDI Z. Relationship between Environmental Quality and Economic Growth in Developing Countries (based on Environmental Performance Index). Environmental Energy and Economic Research, 1 (3), 299, 2017.

25. AL-MULALI U., LEAN H.H. The influence of economic growth, urbanization, trade openness, financial development, and renewable energy on pollution in Europe. Natural Hazards, 79, 621, 2015.

26. CHANG C., DONG M., LIU J. Environmental Governance and Environmental Performance. SSRN Electronic Journal, 2019.

27. BELTRÁN-ESTEVE M., PICAZO-TADEO A.J. Assessing environmental performance in the European Union: Ecoinnovation versus catching-up. Energy Policy, 104, 240, 2017.

28. HALKOS G., ZISIADOU A. Relating environmental performance with socioeconomic and cultural factors. Environmental Economics and Policy Studies, 20 (1), 69, 2018.

29. PIMONENKO T., LYULYOV O., CHYGRYN O., PALIENKO M. Environmental Performance Index: relation between social and economic welfare of the countries. Environmental Economics, 9 (3), 1, 2018.

30. JAHN D. Environmental performance and policy regimes: Explaining variations in 18 OECD-countries. Policy Sciences, 31 (2), 107, 1998.
31. ALMEIDA T.A.N., GARCÍA-SÁNCHEZ I.M. Sociopolitical and economic elements to explain the environmental performance of countries. Environmental Science and Pollution Research, 24 (3), 3006, 2017.

32. PESARAN M.H. A simple panel unit root test in the presence of cross-section dependence. Journal of Applied Econometrics, 22 (2), 265, 2007.

33. ROMEIS J., COLLATZ J., GLANDORF D.C.M., BONSALL M.B. The value of existing regulatory frameworks for the environmental risk assessment of agricultural pest control using gene drives. Environmental Science and Policy. Elsevier Ltd, 2020, June 1.

34. YU J., LO C.W.-H., LI P.H.Y. Organizational Visibility, Stakeholder Environmental Pressure and Corporate Environmental Responsiveness in China. Business Strategy and the Environment, 26 (3), 371, 2017.

35. GUPTA A.K., GUPTA N. Effect of corporate environmental sustainability on dimensions of firm performance - Towards sustainable development: Evidence from India. Journal of Cleaner Production, 253, 119948, 2020.

36. LIAO Z., XU C.K.E., CHENG H., DONG J. What drives environmental innovation? A content analysis of listed companies in China. Journal of Cleaner Production, 198, 1567, 2018.

37. PENG X., LIU Y. Behind eco-innovation: Managerial environmental awareness and external resource acquisition. Journal of Cleaner Production, 139, 347, 2016.

38. FAROOQ M.U., SHAHZAD U., SARWAR S., ZAIJUN L. The impact of carbon emission and forest activities on health outcomes: Empirical evidence from China. Environmental Science and Pollution Research, 26 (13), 12894, 2019.

39. AL-MULALI U., LEAN H.H. The influence of economic growth, urbanization, trade openness, financial development, and renewable energy on pollution in Europe. Natural Hazards, 79, 621, 2015.

40. WANG J., DONG K. What drives environmental degradation? Evidence from 14 Sub-Saharan African countries. Science of the Total Environment, 656, 165, 2019.

41. RAUF A., LIU X., AMIN W., OZTURK I., REHMAN O.U., HAFEEZ M. Testing EKC hypothesis with energy and sustainable development challenges: A fresh evidence from Belt and Road Initiative economies. Environmental Science and Pollution Research, 25 (32), 32066. Retrieved from https://link.springer.com/article/10.1007/s11356-0183052-5, 2018.

42. PESARAN M.H., SCHUERMANN T., WEINER S.M. Modeling Regional Interdependences Using a Global Error-Correcting Macroeconometric Model. Journal of Business and Economic Statistics, 2004, April.

43. FREES E.W. Assessing cross-sectional correlation in panel data. Journal of Econometrics, 69 (2), 393, 1995.

44. FREES E. Longitudinal and panel data. Analysis and applications in the social sciences, 2004.

45. FRIEDMAN M. The Use of Ranks to Avoid the Assumption of Normality Implicit in the Analysis of Variance. Journal of the American Statistical Association, 32 (200), 675, 1937.

46. IM K.S., PESARAN M.H., SHIN Y. Testing for unit roots in heterogeneous panels. Journal of Econometrics, 115 (1), 53, 2003.

47. PESARAN M.H. A simple panel unit root test in the presence of cross-section dependence. Journal of Applied Econometrics, 22 (2), 265, 2007. 
48. CHOI I. Combination unit root tests for cross-sectionally correlated panels. In Econometric Theory and Practice: Frontiers of Analysis and Applied Research (pp. 311-333). Cambridge University Press, 2006.

49. WESTERLUND J. New Simple Tests for Panel Cointegration. Econometric Reviews, 24 (3), 297, 2005.

50. ENGLE R.F., GRANGER C.W.J. Co-integration and error correction: Representation, estimation, and testing. Applied Econometrics, 39 (3), 107, 2015.

51. ENGLE R., GRANGER C. Cointegration And ErrorCorrection: Representation, Estimation And Testing. Econometrica, 55, 251, 1987.

52. KHAN M.T.I., ALI Q., ASHFAQ M. The nexus between greenhouse gas emission, electricity production, renewable energy and agriculture in Pakistan. Renewable Energy, 118, 437, 2018.

53. PEDRONI P. Fully modified OLS for heterogeneous cointegrated panels. In Nonstationary Panels, Panel Cointegration, and Dynamic Panels 15, 93. Emerald Group Publishing Limited, 2001.

54. CHANG C., DONG M., LIU J. Environmental Governance and Environmental Performance. SSRN Electronic Journal, 2019.

55. EL ANSHASY A. Energy intensity and environmental performance in the Gulf Cooperation Council region: a heterogeneous panel approach. The Business and Management Review, 7, 107, 2016.

56. SINHA A. Trilateral association between $\mathrm{SO}_{2} / \mathrm{NO}_{2}$ emission, inequality in energy intensity, and economic growth: A case of Indian cities. Atmospheric Pollution Research, 7 (4), 647, 2016.

57. CHARFEDDINE L., KAHIA M. Impact of renewable energy consumption and financial development on $\mathrm{CO}_{2}$ emissions and economic growth in the MENA region: A panel vector autoregressive (PVAR) analysis. Renewable Energy, 139, 198, 2019.

58. TOYNBEE P. To what extent could planting trees help solve climate change ? Retrieved December 2, 2020, from https://www.theguardian.com/environment/2012/nov/29/ planting-trees-climate-change, 2015.

59. SUSAN MINNEMEYER N.H. and O.P. Conserving Forests Could Cut Carbon Emissions As Much As
Getting Rid of Every Car on Earth. World Resources Institue. Retrieved December 2, 2020, from https:// www.wri.org/blog/2017/11/conserving-forests-could-cutcarbon-emissions-much-getting-rid-every-car-earth 2017, November 27.

60. AHMA, O. How forests help tackle carbon emissions: lessons from India, China and South Korea. Retrieved December 2, 2020, from https:/www.thethirdpole.net/ en/2017/11/16/forests-tackle-carbon-emissions-indiachina-south-korea/ 2017, November 16.

61. SCHWEIER J., MAGAGNOTTI N., LABELLE E.R., ATHANASSIADIS D. Sustainability Impact Assessment of Forest Operations: a Review. Current Forestry Reports. Springer International Publishing, 2019, September 15.

62. MITEVA D.A., LOUCKS C.J., PATTANAYAK S.K. Social and environmental impacts of forest management certification in Indonesia. PLoS ONE, 10 (7), e0129675, 2015.

63. SONESSON U., BERLIN J., HOSPIDO A. Towards sustainable industrial food production using Life Cycle Assessment approaches. In Environmental Assessment and Management in the Food Industry (pp. 165-176). Elsevier, 2010.

64. RAMOS S., ETXEBARRIA S., CIDAD M., GUTIERREZ M., SAN MARTIN D., IÑARRA B., ZUFIA J. Cleaner production strategies for the food industry. In The Interaction of Food Industry and Environment (pp. 1-34). Elsevier, 2020.

65. AYOUB A.T. Fertilizers and the environment. Nutrient Cycling in Agroecosystems, 55 (2), 117, 1999.

66. LI W., GUO S., LIU H., ZHAI L., WANG H., LEI Q. Comprehensive environmental impacts of fertilizer application vary among different crops: Implications for the adjustment of agricultural structure aimed to reduce fertilizer use. Agricultural Water Management, 210, 1, 2018.

67. CHIEN S.H., PROCHNOW L.I., CANTARELLA H. Chapter 8 Recent Developments of Fertilizer Production and Use to Improve Nutrient Efficiency and Minimize Environmental Impacts. Advances in Agronomy. Academic Press Inc, 2009, January 1. 
